\title{
Author's Reply to Petersen: “Differences in In Vitro Properties of Pancreatin Preparations for Pancreatic Exocrine Insufficiency as Marketed in Russia and CIS"
}

\author{
Igor V. Maev ${ }^{1}$ - Yury A. Kucheryavyy ${ }^{1} \cdot$ Natalya B. Gubergrits $^{1} \cdot$ Ingo Bonnacker $^{1} \cdot$ Ekaterina A. Shelest $^{1}$. \\ Gwendolyn P. Janssen-van Solingen ${ }^{1}$ (D) . J. Enrique Dominguez-Munoz ${ }^{1}$
}

Accepted: 20 September 2021 / Published online: 23 October 2021

(c) The Author(s) 2021

Referring to the Letter to the Editor by Prof. Dr. Karl-Uwe Petersen [1] regarding our article entitled Differences in In Vitro Properties of Pancreatin Preparations for Pancreatic Exocrine Insufficiency as Marketed in Russia and $C I S$ [2], we would like to provide further information and feedback.

Our investigation has indeed focused on Feret $\max X_{50}$ as the selected representative parameter for particle size measurements. As explained in the publication, this was used as a representative parameter for the overall particle size diameter (PSD), for which the cumulative distribution Q3 (volume-based) assumes a value of 50\%, where $\mathrm{X}_{50}$ represents the particle size at which $50 \%$ of particles in the material are smaller than this. Within the study, $X_{10}$ and $X_{90}$ have also been determined (data on file). For the $\mathrm{X}_{90}$ max assessments, Kreon has the lowest PSD (approximately $2000 \mu \mathrm{m}$ ) compared with all other pancreatin preparations (approximately $3000 \mu \mathrm{m}$ ). Upon evaluation of the $\mathrm{X}_{10}$ results, the preparations meeting a particle size smaller than $2000 \mu \mathrm{m}$ are Kreon 25000, Kreon 40000, and Micrazim 25000 and 40000. All other preparations, including Ermytal (both strengths), Pangrol, and Panzytrat, still do not meet a particle size smaller than $2000 \mu \mathrm{m}$. Even when assessing the Feret $\min \mathrm{X}_{50}$ data, only Kreon and Micrazim preparations are below $1500 \mu \mathrm{m}$, with averages of $1121 \mu \mathrm{m}$ for Kreon and $1389 \mu \mathrm{m}$ for Micrazim. The authors therefore believe that the choice of $\mathrm{X}_{50}$ is justified and supportive of the United European Gastroenterology Diagnosis and Treatment of Chronic Pancreatitis (UEG/HaPanEU) guideline consensus

This reply refers to the comment available online at https://doi.org/ 10.1007/s40268-021-00366-Z.

Gwendolyn P. Janssen-van Solingen gwendolyn.janssen@abbott.com

1 Abbott Product Operations AG, Allschwil, Switzerland statement [3] and previously published comparative studies assessing the in vitro properties of different pancreatin preparations.

Prof. Dr. Karl-Uwe Petersen mentions that the conclusion of the abovementioned HaPanEU guideline [3] has been challenged, particularly in his systematic review from March 2021 [4], which succeeds our publication; however, the authors would like to point out that the systematic review is based on publications currently in the public domain and is not reflective of the full dataset for our particular study and the pancreatin preparations available in Russia/Commonwealth of Independent States (CIS). Additionally, contrary to what is being postulated and as mentioned in the publication by Prof. Dr. Karl-Uwe Petersen; the pancreatin preparations assessed, including Kreon, do not have a round shape but rather a more cylindrical shape, where the Feret min diameter represents the diameter of the cylinder and the Feret max represents the maximum size of the particle in any dimension, thereby being indicative of the probability of the particle passing the pylorus together with the chyme.

We also note that Prof. Dr. Karl-Uwe Petersen only addresses the PSD and the max Feret $\mathrm{X}$ value in his Letter to the Editor [4], and does not comment on the other differences between the specific pancreatin preparations identified in our in vitro investigation, particularly the differences observed regarding lipase activity (with Micrazim 40000 being a significant outlier at $79 \%$ of the declared lipase content) and (associated) dissolution [2] - variables likely having an even greater impact on digestive potency and clinical efficacy.

We therefore re-emphasize the conclusion drawn in our publication - aligned with the HaPanEU guidelines and previous investigations - that pancreatin preparations with a diameter of $<2 \mathrm{~mm}$ should be regarded as optimal for the treatment of pancreatic exocrine insufficiency (PEI), combined with clinical efficacy data generated with said 
preparations as well as enzyme activity and optimal dissolution characteristics.

Funding The research was supported by Abbott Pharmaceuticals.

\section{Declarations}

Conflicts of interest Igor V. Maev, Yury A. Kucheryavyy, and Natalya B. Gubergrits have no conficts of interest that are directly relevant to the content of the original article or the Reply to the Letter to the Editor. Dr. J. Enrique Domínguez-Muñoz has received research grants from Abbott Pharmaceuticals and Mylan; payment for lectures from Abbott and Mylan; and paid consultancy from Mylan. Ingo Bonnacker, Ekaterina A. Shelest, and Gwendolyn P. Janssen-van Solingen are employed by Abbott Pharmaceuticals.

Open Access This article is licensed under a Creative Commons Attribution-NonCommercial 4.0 International License, which permits any non-commercial use, sharing, adaptation, distribution and reproduction in any medium or format, as long as you give appropriate credit to the original author(s) and the source, provide a link to the Creative Commons licence, and indicate if changes were made. The images or other third party material in this article are included in the article's Creative Commons licence, unless indicated otherwise in a credit line to the material. If material is not included in the article's Creative Commons licence and your intended use is not permitted by statutory regulation or exceeds the permitted use, you will need to obtain permission directly from the copyright holder. To view a copy of this licence, visit http://creativecommons.org/licenses/by-nc/4.0/.

\section{References}

1. Petersen KU. Comment on: "Differences in in vitro properties of pancreatin preparations for pancreatic exocrine insufficiency as marketed in Russia and CIS". Drugs RD. https://doi.org/10.1007/ s40268-021-00366-z

2. Maev IV, Kucheryavyy YA, Gubergrits NB, Bonnacker I, Shelest EA, Janssen-van Solingen GP, et al. Differences in in vitro properties of pancreatin preparations for pancreatic exocrine insufficiency as marketed in Russia and CIS. Drugs RD. 2020;20:36976. https://doi.org/10.1007/s40268-020-00326-z.

3. Löhr JM, Domínguez-Muñoz JE, Rosendahl J, Besselink M, Mayerle J, Lerch MM, et al. United European Gastroenterology evidence-based guidelines for the diagnosis and therapy of chronic pancreatitis (HaPanEU). United Eur Gastroenterol J. 2017;5:15399. https://doi.org/10.1177/2050640616684695.

4. Petersen K-U, Malfertheiner P, Mössner J. The role of sphere size in the context of pancreatin therapy for exocrine pancreatic insufficiency: a systematic review. J Gastrointest Liver Dis. 2021;30(1):132-41. https://doi.org/10.15403/jgld-2985. 